\title{
Corporate sustainability and social responsibility
}

\author{
Zeynegul Samaibekova ${ }^{*}$, Gulzhamal Choyubekova ${ }^{2}, K_{\text {erezkan }}$ Isabaeva $^{3}$, and Asel \\ Samaibekova ${ }^{4}$ \\ ${ }^{1}$ Institute of Economics and Management, Kyrgyz State University of Construction, Transport and \\ Architecture named after N. Isanov, Maldybaev str. 34b, Bishkek, Kyrgyz Republic \\ ${ }^{2}$ Department of Public Health and Health care, Kyrgyz State Medical Academy named after \\ I.K.Ahunbayev, I.Akhunbaeva str. 92, Bishkek, Kyrgyz Republic \\ ${ }^{3}$ Department of Economics and Enterprise Management, Kyrgyz State University of Construction, \\ Transport and Architecture named after N. Isanov, Maldybaev str. 34b, Bishkek, Kyrgyz Republic \\ ${ }^{4}$ Department of Economics and Management, Kyrgyz State University named after Arabaeva, \\ Razzakov str. 49, Bishkek, Kyrgyz Republic
}

\begin{abstract}
Our paper focuses on the links between corporate sustainability and social responsibility. Corporate Social Responsibility (CSR) emerged as a tool for linking the priorities of business companies (making money and achieving profit) with the priorities of citizens and society. Bringing together the many different parts of a complex CSR programme into a single central system is crucial. Moreover, we discuss the role of corporate structures in the development of social organisations and their impact on society, as well as on corporate social responsibility and the impact of the social entrepreneurship model on the economy. It appears that companies can bring important benefits to society if they are responsible for the quality of the goods and services they produce and develop new goods or services that generate economic growth. The long-term benefits for investors therefore allow companies to invest in product innovation, thereby delivering highquality products that improve people's standard of living. Business companies thus meet the needs of society and offer important benefits to society in the form of new jobs and economic opportunities for those in society who depend on the company's good services. While companies seek new economic opportunities and regain public confidence, the creation of shared values and the pursuit of financial success is becoming increasingly important for companies in a way to support sustainable development and fighting global warming and climate change.
\end{abstract}

\section{Introduction}

Corporate Social Responsibility (CSR) is a comprehensive concept that can take many forms depending on the company and industry [1]. Commitment to CSR means that a company works in a way that promotes society and the environment, rather than contributing negatively [2]. Technology can help implement a CSR program that includes reducing any

\footnotetext{
*Corresponding author: samaibekova@mail.ru
} 
company's carbon footprint for the benefit of the planet. Companies can not only strengthen their brand, but also benefit from society in other ways, such as in the form of education, employment and the environment. Corporate sustainability and social responsibility (CSR) have become a strategic imperative for companies, as they are an integral part of the optimal long-term strategy [3,4]. Therefore, companies should make decisions and develop processes to achieve greater financial success where consumers are an important stakeholder and where consumers are an important and important stakeholder for the long-term success of the company. But as important as CSR is to the community, CSR is valuable to businesses. Businesses worldwide are developing strategies to become better corporate citizens and communicating their activities to internal and external stakeholders, who can involve a range of groups [5].

While organizations want to promote employee engagement, build brand values and, above all, achieve sustainable change in the local community, improving CSR management around sustainability has become a central pillar of their cause. Modern CSR managers behave in a promising way and help them and their initiatives to achieve high organisational goals [6].

In addition, human resources professionals can understand their influence and respect for CSR, and these insights can be shared with the rest of the organization to integrate into their business model. Human resources management can play an important role in developing a corporate social responsibility strategy to ensure that it is what it is doing here [7]. They can reward and incentivize good decisions and initiatives and encourage collaboration and collaboration between employees, families of employees and other stakeholders. In addition, human resources departments play a crucial role in ensuring that companies implement CSR responsibility programmes. Thy can increase the awareness of the employer brand, increase employee engagement, increase shareholder value and increase the value of their shareholders. HR can monitor the introduction of CSR and manage its implementation while documenting and celebrating success across the company, tracking and reporting on success.

\section{Strengthening business connection with the society}

It takes a lot of time and energy to build good, strong and lasting business relationships today, and people do not seem to want to participate, but it is an integral and necessary part of anyone's success. In society, people function in relationships and they are in business [8]. But lasting business relationships do not develop or develop without dedicated and consistent work. Although there are many strong relationships that have been established in our community, some are not the most effective, and sometimes it is not what one knows, but who she or he knows. People learn the skills to build and maintain relationships over time.

In order to attract and retain new and existing customers, one needs to devote resources and invest in building strong, long-term business relationships that help people recognize the value and achieve their goals with a specific product or service. Simply put, to be successful, a company must build a positive relationship with its customers. This is because building relationships with new and potential customers enables companies to offer a more personalised and enticing customer experience [9]. It is more than just responding to e-mails on time, sending e-mail marketing campaigns with discounts, or being polite on the phone. One should think of improving customer contact points with the sales, marketing and support teams. In most cases, one can handle communication with loyal customers willing to support one's business through mouth marketing. Ultimately, this becomes a measure of a business company's ability to build a positive relationship with a company's customers [10].

To build a positive relationship with their customers, companies often rely on technology and create a central command centre to manage, monitor and communicate with customers. Some companies have managed to build a stable business that has strengthened over the 
years, while others have had huge volatility and eventually closed. While many factors lead to success, one essential step is to establish a strong business relationship with a customer who returns with time and sends future business as a recommendation. A strong customer relationship requires active communication, and that means that the customer must feel comfortable approaching the business company and its managers. The customers should know that the business is always available by phone, social media, email or in person [11].

One of the biggest dangers of communication is that a customer cannot find out if the other person understands the message she or he is trying to convey. Poor workplace communication can lead to a culture of back-biting and blame-pointing, which can affect stress levels when the customers do not understand or feel deceived. If a business company works well and motivates people to come to work and do good work, it has a positive effect on morale. This is a fundamental attitude that can bring endless benefits to any business. The simple act of appreciation can increase productivity, improving the quality of work and achieving better returns. This can take the form of better customer service, not to mention a happier environment, which generally creates a better working relationship between a business company and its employees as well as its customers.

\section{Business company and its contribution to social development}

In general, there is a strong link between social media and social networks such as Facebook and Twitter. Running corporate responsibility campaigns as a quick marketing program can backfire if the company does not hold out. One can adopt socially responsible business practices by applying a one-off action rather than a long-term strategy [12].

Employees and consumers react positively to companies that take on long-term social responsibility but not always positively. The apparent acceptance of CSR in the economy has been taken up by many economists, but not Milton Friedman who claimed that the only social responsibility of companies was to maximise their profits by doing business in open and free competition without fraud or deception. Friedman pointed out that shareholders, customers and employees could spend their own money on social activities if they wanted to. However, he also pointed out that there were many circumstances in which company managers could take measures that served the long-term interests of the company owner but indirectly had positive social effects [13].

In the search for the best categories, the only categories in which a significant proportion of companies were in the category "goods". In the area of human rights, all categories of business companies behave similarly, with some firms showing relative strength. This is understandable, because companies in this category face strong opposition from activists who are concerned about the unskilled labour that is normally employed in developing countries during the production process.

Modern theoretical and empirical analyses show that companies can engage in strategically socially responsible activities and at the same time increase their private profits. Becoming a socially responsible company can be easy, even if there are a few caveats. Any company should avoid participating in charitable efforts that are not related to its core business or that in any way violate its ethical standards. Instead of blindly sending money to completely independent organizations, you can find non-profit organizations your company believes in, projects and communities one works with. Corporate citizenship is one of the most important aspects of corporate social responsibility. Corporate citizenship is important to business and thence we can ensure that organisations are socially responsible. Businesses are interchangeable, but the latter is only one facet of the former [14]. Companies can exercise social responsibility by donating money, products or services to social causes and non-profit organisations. Charitable donations include donations and grants to non-profit organizations. Large companies tend to have ample resources to benefit charities, local communities, and 
programs; but for small businesses, such efforts can make a big difference. One of the greatest values a company should promote is the ability to provide knowledge. If there is a particular charity or programme you have in mind, contact the organisation and ask them what organisation would help you best and why. This is not the only way to actively participate, but it is crucial that we share what we know, and only then can we do our best together. If one is considering a sustainable activity that is not yet legally mandatory, it is not good to wait until it is legal. If one adopts socially responsible standards early on, she or he can set the bar and refine the process over time and refine the process further in the future [15].

Their impact measures can make a real difference in the world and appeal to socially conscious consumers and employees. Corporate social responsibility was introduced as an approach to international development. It enables certain stakeholders to redefine the meaning of international development success. The interests of companies are not adequately aligned with those of the poor, and explains why CSR does little to change this. There is a historical relationship between business and development and compares how expectations of companies that live by CSR practices differ from those of the past. There should be a new societal approach to CSR, while the new challenge for companies is the lack of a clear understanding of their role in social development. The focus will be on the role of corporate responsibility in the development of social and environmental sustainability [16].

\section{Social and environmental programmes and CSR}

All of the above being said, one can recall that corporate social responsibility refers to the growing practice of for-profit organizations aligned to relevant purposes and good social programs [17]. A recent employees survey found that more than half of respondents are willing to pay more for products and services from companies that are committed to positive social and environmental impacts, and two-thirds would prefer to work for these companies [18]. Companies that hire people who are strongly committed to social justice, environmental sustainability, and human rights also benefit from the public interest in making the world a better place, according to a new study. It is important to recognize and celebrate socially responsible companies, to promote their work and to show other organizations how they can successfully integrate social welfare into their mission.

Furthermore, a commitment to CSR means that a company works in a way that promotes society and the environment, rather than contributing negatively to it [19]. In this way, companies can benefit society and at the same time increase their brand and thus their profit and reputation. Corporate social responsibility enables large and small companies to implement positive changes. As important as CSR is to the community, it is valuable to businesses and to society as a whole. Consumers feel that they are playing their part in using products and services from socially responsible companies. When companies choose to do what is in the best interests of their customers and the community, they benefit financially by building trust with consumers. The more socially responsible a company is, the more supportive communities and consumers become. The more visible and successful a company is, the more responsibility it must assume for its employees, the families of its employees and the community as a whole. Although it is not as good - and is promoted by large corporations - small and medium-sized enterprises are creating social responsibility programs as part of their business model.

Companies that implement CSR benefit in many ways. For example, Starbucks has long been known as one of the world's largest companies, strongly committed to social and environmental responsibility. Starbucks says it has achieved many of its CSR milestones since it opened. With the increasing use of corporate responsibility, it is becoming increasingly important to have a socially conscious image [20]. Consumers, employees and stakeholders prioritize CSR when choosing a brand or company, and they make companies 
responsible for driving social change through their business beliefs, practices and profits. To illustrate just how critical social responsibility becomes, one recent research found that more than $60 \%$ of Americans hope that, without government regulation, companies will drive social and environmental change, underscoring the importance of corporate responsibility as a key element of their business model [21].

One of the ways global communications companies can achieve social impact is through private corporate social initiatives which support promising start-ups focused on environmental, social, health, human rights, and social justice issues. Such instantiates support for-profit start-ups by guiding companies through the early stages of business, providing access to mentorship, and facilitating pitch placement for potential investors. Many companies have national sustainability programs and invest millions in sustainability and conservation projects. By combining philanthropy and the corporate sector through CSR, stakeholders can bring about environmental change while encouraging other companies to follow in their footsteps and be environmentally friendly. Businesses have a strong influence on the economy and have more resources than non-profit organizations to change their policies, which allows them to act as change agents.

All in all, corporate social responsibility is an opportunity for companies to make a difference in the community. With available corporate profits, CSR programs can not only invest in non-profit sectors, but also promote positive change in communities. There is an increasing pressure on American companies to make meaningful contributions to the greater social good by consumers, workers and investors. Today, many consumers state they would be more likely to buy a company's products and services if the company were to address social, economic and environmental issues. A 2019 study of millennials by Deloitte found that climate change and environmental protection are at the top of millennials' concerns. CSR is a fast-growing field but most large companies have not yet adopted a CSR programme which is both sad and surprising [22].

\section{Conclusions}

Businesses are highly profit-oriented hybrid social organizations, which sometimes find it difficult to focus on economically sustainable models rather than on solving social problems. Companies that seek profit are often presented as organizations with charitable goals, assuming that a profit-oriented institutional environment performs better than a charity-oriented one. For profit is also encouraged to donate to charity, to establish affiliated foundations and to pursue social goals in addition to maximizing profits through state stakeholder laws. These include companies with profit structures that integrate social welfare into their objectives, as well as those without profit structures that integrate social goods into their objectives. If a for-profit company can tap a large pool of investment capital, a social mission could fit well into it. But if it is not part of the legal structure, then a profit that brings social benefits must have a founder or board of directors who firmly believes in the cause and is willing to invest money in it, even if it conflicts with the company's profit objectives.

Companies that go further than traditional CSR are often referred to as purpose-oriented organisations. In addition, social welfare is not only part of the corporate structure, but also the business model and business strategy of the company. We often hear in the business world that we are focusing on entrepreneurial practices that lead to higher monetary profitability. We give people who are involved in the organisation a sense of importance, draw on their support, explain how they make a difference and give something back. Since these two types of entrepreneurs are driven by different motivations, we must bear in mind that their businesses will function a little differently. Social enterprise means using market-based business strategies to advance the social and environmental impact of an organization. Social enterprises, on the other hand, focus on achieving social, environmental and economic 
profitability. In other words, social enterprise constitutes a market-driven approach for businesses that is used effectively to solve social problems. Social entrepreneurs face serious challenges in finding innovative and practical solutions. Companies need steady capital flow, innovation requires experimentation, and there is little incentive to pay for unproven approaches. As a result, those who finance social entrepreneurship projects focus on shortterm gains, not long-term social impact. Social entrepreneur projects tend to offer investors lower returns than other opportunities. Relations between social entrepreneurs and investors can be strained by conflicting objectives and conflicts of interest, but also by the fact that innovation requires experimentation. All in all, corporate social responsibility helps to establish corporate sustainability and helps businesses to grow and to evolve in accordance with the environmental and green agenda of the $21^{\text {st }}$ century.

\section{References}

1. B. Xia, A. Olanipekun, Q. Chen, L. Xie, Y. Liu, Journal of Cleaner Production, 195, 340-353 (2018)

2. A. Dwekat, E. Seguí-Mas, G. Tormo-Carbó, P. Carmona, Corporate Social Responsibility and Environmental Management, 27(6), 2879-2892 (2020)

3. J. Lu, L. Ren, J. Qiao, S. Yao, W. Strielkowski, J. Streimikis, Sustainability, 11(15), 4128 (2019)

4. M. Ashrafi, M. Adams, T. R. Walker, G. Magnan, International Journal of Sustainable Development \& World Ecology, 25(8), 672-682 (2018)

5. L.M. Edinger-Schons, L. Lengler-Graiff, S. Scheidler, G. Mende, J. Wieseke, Business Ethics: A European Review, 29(3), 510-527 (2020)

6. R. Cannas, G. Argiolas, F. Cabiddu, Journal of Sustainable Tourism, 27(1), 139-155 (2019)

7. M.A.L. Agudelo, L. Jóhannsdóttir, B. Davídsdóttir, International Journal of Corporate Social Responsibility, 4(1), 1-23 (2019)

8. Y. Doz, Human Resource Management Review, 30(1), 100693 (2020)

9. W. Wikhamn, International Journal of Hospitality Management, 76, 102-110 (2019)

10. M. Preziosi, P. Tourais, A. Acampora, N. Videira, R. Merli, Journal of Cleaner Production, 237, 117659 (2019)

11. F.S. Foltean, S.M. Trif, D.L. Tuleu, Journal of Business Research, 104, 563-575 (2019)

12. V. Kumar, A. Lahiri, O.B. Dogan, Industrial Marketing Management, 69, 147-160 (2018)

13. T.L. Carson, Business and Society Review, 123(2), 217-242 (2018)

14. P. Wan, X. Chen, Y. Ke, Journal of Cleaner Production, 259, 120877 (2020)

15. J. Lu, L. Ren, S. Yao, J. Qiao, W. Strielkowski, J. Streimikis, Energies, 12(18), 3417 (2019)

16. G.K. Stahl, C.J. Brewster, D.G. Collings, A. Hajro, Human Resource Management Review, 30(3), 100708 (2020)

17. P. Gazzola, M. Ratti, S. Amelio, Management Dynamics in the Knowledge Economy, 5(3), 355-376 (2017)

18. L. Kong, M.S. Sial, N. Ahmad, M. Sehleanu, Z. Li, M. Zia-Ud-Din, D. Badulescu, Sustainability, 13(3), 1499 (2021)

19. D. Smith, E. Rhiney, International Journal of Corporate Social Responsibility, 5(1), 1$12(2020)$

20. E. Gozdan, A. Sudolska, Journal of Corporate Responsibility and Leadership, 6(2), 2947 (2019)

21. P. Shrivastava, M.S. Smith, K. O’Brien, L. Zsolnai, One Earth, 2(4), 329-340 (2020) 
22. Deloitte, https://www2.deloitte.com/content/dam/Deloitte/global/Documents/AboutDeloitte/deloitte-2019-millennial-survey.pdf (2019) 